\title{
Penile Epithelioid Hemangioma
}

National Cancer Institute

\section{Source}

National Cancer Institute. Penile Epithelioid Hemangioma. NCI Thesaurus. Code C162580.

An epithelioid hemangioma that occurs in the skin of the penis. 